\title{
Genetic structure analysis of Eufriesea violacea (Hymenoptera, Apidae) populations from southern Brazilian Atlantic rainforest remnants
}

\author{
Silvia H. Sofia ${ }^{1}$, Francine M. de Paula ${ }^{1}$, Aline M. dos Santos ${ }^{2}$, Fernanda S. Almeida ${ }^{1}$ \\ and Leda M.K. Sodré ${ }^{1}$ \\ ${ }^{1}$ Universidade Estadual de Londrina, Centro de Ciências Biológicas, Departamento de Biologia Geral, \\ Londrina, Paraná, Brazil. \\ ${ }^{2}$ Universidade de São Paulo, Faculdade de Medicina de Ribeirão Preto, Departamento de Genética, \\ Ribeirão Preto, SP, Brazil.
}

\begin{abstract}
Random amplified polymorphic DNA (RAPD) markers were used to analyze the genetic structure of Eufriesea violacea populations in three fragments $(85.47,832.58$ and $2800 \mathrm{ha})$ of Atlantic rainforest located in the north of the Brazilian state of Paraná. A total of twelve primers produced 206 loci, of which 129 were polymorphic (95\% criterion). The proportions of polymorphic loci in each population ranged from $57.28 \%$ to $59.2 \%$, revealing very similar levels of genetic variability in the groups of bees from each fragment. Unbiased genetic distances between groups ranged from 0.0171 to 0.0284 , the smallest genetic distance occurring between bees from the two larger fragments. These results suggest that the $E$. violacea populations from the three fragments have maintained themselves genetically similar to native populations of this species originally present in northern Paraná.
\end{abstract}

Key words: euglossine bees, euglossina, rainforest fragments, genetic variability, RAPD.

Received: June 7, 2004; Accepted: April 18, 2005.

Euglossines are relatively long-tongued bees, commonly showing a bright metallic blue, green or bronze integument, and are found exclusively in Neotropical America (Dressler, 1982; Cameron, 2004). Male euglossines are not tied to a nest but leave it upon hatching (Dodson, 1966; Dressler, 1982) and both female and male euglossine bees often fly long distances between dispersed resources, making them especially important in crosspollination of widely scattered plant species in tropical forests (Janzen, 1971). However, some studies have shown that habitat fragmentation may adversely affect populations of such pollinators and evidence suggests that in isolated Brazilian rainforest fragments there has been a decline in the number of males in some euglossine species (Powell and Powell, 1987; Becker et al., 1991). Furthermore, despite being able to fly long distances in continuous forest, deforested areas only $100 \mathrm{~m}$ wide have created barriers to the movement of some euglossine species (Powell and Powell, 1987).

It is known that genetic variability can be substantially reduced in small and isolated populations through ge-

Send correspondence to Silvia Helena Sofia. Universidade Estadual de Londrina, Centro de Ciências Biológicas, Departamento de Biologia Geral, Caixa Postal 6001, 86051-990 Londrina, Paraná, Brazil. E-mail: shsofia@uel.br. netic drift and inbreeding, resulting in the loss of alleles and a decline in heterozygosity. Such reductions may result in decreased fitness and the eventual extinction of populations (Fergunson et al., 1995). Thus, it is now widely appreciated that understanding patterns of genetic variation is critically important for the conservation of threatened species (Allnut et al., 2003).

During the past thirty years, advances in molecular technology have greatly increased the number of DNA-based markers capable of revealing genetic variation in a wide range of species. Random amplified polymorphic DNA (RAPD) analysis, a simple and straightforward PCR-based technique (Williams et al., 1990), employs a class of markers increasingly used to evaluate genetic variability and structure in a variety of organisms (Kimberling et al., 1996; Almeida et al., 2001; Allnutt et al., 2003).

Despite the recognized importance of euglossine bees as Neotropical pollinating agents, little is yet known about the genetic variability and structure of populations of these bees inhabiting forest fragments.

A number of studies carried out in remnants of Atlantic rainforest in southeastern Brazil have revealed variation in the frequencies of males belonging to the euglossine bee species Eufriesea violacea (Blanchard) (Rebêlo and Garófalo, 1991; Garófalo et al., 1998; Jesus and Garófalo, 
2000), a very seasonal species of bees mainly found in south and southeastern Brazilian Atlantic rainforest (Wittmann et al., 1989; Rebêlo and Garófalo, 1991; Peruquetti and Campos, 1997). Sofia and Suzuki (2004) have reported that a reduction in fragment size negatively affected the frequency of $E$. violacea males.

During the research presented in this paper we studied E. violacea in terms of its possible sensitivity to environmental disturbances, because changes in the relative abundance of individuals could be the result of species susceptibility to environmental stress. The aim of our study was to use RAPD markers to investigate the genetic variability and structure of Eufriesea violacea populations occurring in three southern Brazilian Atlantic rainforest remnants.

Samples were collected in three Brazilian Atlantic rainforest remnants (all public reserves) composed of subtropical semi-deciduous vegetation (Fernandes and Bezerra, 1990), which were located in the north of the southern Brazilian state of Paraná (Figure 1).

Godoy Forest State Park (GF fragment) lies within the Londrina municipal boundary $\left(23^{\circ} 27^{\prime} \mathrm{S}, 51^{\circ} 15^{\prime} \mathrm{W}\right)$ about $15 \mathrm{~km}$ from the center of the city of Londrina and consists of a 580 ha area of very well-preserved native vegetation continuous with another native forest fragment consisting of about 2200 ha situated outside the protected area of the Park but making an effective total fragment area of about 2800 ha of forest.

Arthur Thomas Municipal Park (AT fragment) comprises an 85.47 ha area of secondary vegetation (produced by intense anthropogenic interference) in the urban center of Londrina $14.2 \mathrm{~km}$ from the GF fragment.

The São Francisco State Park (SF fragment) is an 832.58 ha rainforest fragment located between the districts of Cornélio Procópio (2309'10" S, 50³6’10" W) and Santa Mariana $\left(23^{\circ} 14^{\prime} 00^{\prime \prime} \mathrm{S}, 50^{\circ} 31^{\prime} 00^{\prime \prime} \mathrm{W}\right)$ about $60 \mathrm{~km}$ from the GF and AT fragments and is, like the GF fragment, well preserved.

All three fragments show signs of past and present anthropogenic disturbance, with both the GF and SF fragments being surrounded by agricultural crops and the AT fragment being situated inside an urban park.

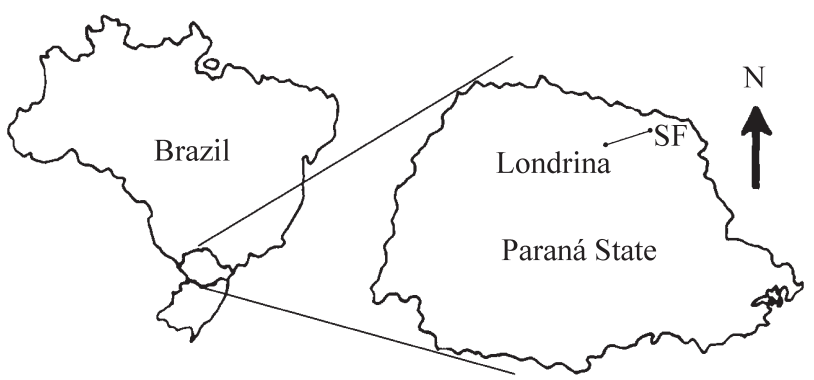

Figure 1 - Location of São Francisco State Park (SF) and Londrina district containing Godoy's Forest State Park and the Arthur Thomas Municipal Park. The sites were all in the north of the southern Brazilian state of Paraná.
Bees were sampled in November and December of 2001 and 2002, between 10:00 a.m. and 1:00 p.m., when euglossine males are most active (Ackerman, 1983; Powell and Powell, 1987; Santos and Sofia 2002). Male euglossines were collected with an insect net when they were attracted to eucalyptol and vanillin chemical baits consisting of $5 \mathrm{~cm}$ diameter balls of absorbent paper saturated with one of the fragrances and placed at the edge of forest about $4 \mathrm{~m}$ apart and $1.5 \mathrm{~m}$ above the ground, the bait chemicals being replenished every hour to prevent volatility losses (Santos and Sofia 2002).

Forty-five males were collected, 15 from each forest fragment, placed in plastic tubes, transported alive to the laboratory and kept frozen $\left(-20{ }^{\circ} \mathrm{C}\right)$ until needed for DNA extraction. The bees were identified by one of the authors (S.H. Sofia) and voucher specimens deposited at the Zoology Museum of Londrina State University (UEL, Londrina Paraná, Brazil).

Total genomic DNA was extracted from each bee by a modification of the method of Raeder and Broda (1985). Each bee was separately ground into a fine powder using liquid nitrogen and a mortar and pestle, the powder subsequently being homogenized in a microcentrifuge tube containing $700 \mu \mathrm{L}$ of extraction buffer ( $1 \%$ sodium dodecyl sulfate, $200 \mathrm{mM}$ Tris- $\mathrm{HCl}, 250 \mathrm{mM} \mathrm{NaCl}, 25 \mathrm{mM}$ EDTA, $\mathrm{pH} 8.0)$ and $5 \mu \mathrm{L}$ of proteinase $\mathrm{K}\left(20 \mu \mathrm{g} . \mu \mathrm{L}^{-1}\right)$ and then incubated for $2 \mathrm{~h}$ at $64{ }^{\circ} \mathrm{C}$. After incubation genomic DNA was extracted with an equal volume of phenol, followed by phenol/chloroform/isoamyl alcohol (25:24:1, v:v:v) and then chloroform/isoamyl alcohol $(24: 1 \mathrm{v}: \mathrm{v})$ which was then mixed and centrifuged at $10,000 \mathrm{~g}$ for $10 \mathrm{~min}$. After centrifugation the DNA was precipitated from the supernatant with two volumes of ice-cold ethanol and 10\% by volume of $3 \mathrm{M} \mathrm{NaCl}$ and pelleted at 13,000 $\mathrm{g}$ for $15 \mathrm{~min}$, washed with $100 \mu \mathrm{L}$ of $70 \%$ ethanol, dried at room temperature and re-suspended in $100 \mu \mathrm{L}$ of TE buffer $(10 \mathrm{mM}$ Tris, $1 \mathrm{mM}$ EDTA $\mathrm{pH}$ 8.0). The DNA concentration was determined in a 200 DyNA Quant fluorometer (Hoefer) using the dye Hoechst 33258, all DNA samples being diluted to a standard concentration of $5 \mathrm{ng} \mu \mathrm{L}^{-1}$. All isolated DNA was either used immediately or stored at $-20^{\circ} \mathrm{C}$.

The RAPD profiles were generated from total genomic DNA as described by Williams et al. (1990). Final reaction volumes were $15 \mu \mathrm{L}$ and contained 15-25 ng of template DNA, $250 \mu \mathrm{M}$ dNTP (Pharmacia), $0.3 \mu \mathrm{M}$ of ten-nucleotide primer (Operon Technologies, Alameda, CA, USA), $4.0 \mathrm{mM} \mathrm{MgCl}_{2}$ and $1 \mathrm{U}$ of DNA polymerase (Biotools) in the reaction buffer supplied. The RAPD technique is sensitive to changes in reaction conditions (e.g. primer, $\mathrm{MgCl}_{2}$, dNTP concentrations etc), so exactly the same reaction conditions were used for all samples. From primer kits OPC, OPW, OPAM, a total of 40 different decamer primers were initially screened with a subset of $E$. violacea DNA samples for the production of clear RAPD 
profiles. Control reactions were run containing all components except genomic DNA and none of the 12 primers used yielded detectable amplified products. DNA amplifications were carried out at in a PTC-100 thermocycler (MJ Research Inc.) and the amplification protocol consisted of 4 min denaturation at $92^{\circ} \mathrm{C}$ followed by 40 cycles of $40 \mathrm{~s}$ at $92{ }^{\circ} \mathrm{C}, 1.5 \mathrm{~min}$ at $40{ }^{\circ} \mathrm{C}$, and $2 \mathrm{~min}$ at $72{ }^{\circ} \mathrm{C}$ with a final step of 5 min at $72{ }^{\circ} \mathrm{C}$.

Samples $(15 \mu \mathrm{L})$ of the amplification products were separated by electrophoresis on $1.4 \%$ agarose gels using TBE buffer $(0.89 \mathrm{mM}$ Tris, $0.89 \mathrm{mM}$ boric acid, $2 \mathrm{mM}$ EDTA pH 8.3) diluted 1:20 (v:v), run at $3 \mathrm{~V} . \mathrm{cm}^{-1}$, stained with ethidium bromide and photographed under UV light using a Kodak T-Max 100 film.

The RAPD marker profiles were determined by direct comparison of the amplified electrophoretic DNA profiles from each individual. Samples of all individuals from each forest fragment were placed on the same agarose gel, so as to make an inter-population comparative analysis. Amplified DNA marker bands were scored in a binary manner as either present (1) or absent (0) and entered into a binary data matrix. Only RAPD bands that could be unequivocally scored were counted in the analysis. Each locus was treated as a two-allele system, with only one of the alleles per locus being amplifiable by the PCR. It was also assumed that marker alleles from different loci did not co-migrate to the same position on a gel, and that populations were under the Hardy-Weinberg equilibrium (Lynch and Milligan, 1994).

A pair-wise similarity matrix was constructed using the Jaccard $(J)$ index (Sneath and Sokal, 1973). On the basis of the $J$-values of the samples the unweighted pair group method with averages (UPGMA) clustering method was adopted and the NTSYS-PC package (Rohlf, 1992) used to generate a similarity dendrogram.

The TFPGA 1.3 software (Miller, 1997) was used to calculate the following: genetic variability as estimated from the proportion of polymorphic loci $(\bar{P})$ using the $95 \%$ criterion; average heterozygosity $(\bar{H} e)$, which estimates the frequency of heterozygotes in a population and is also a measure of genetic variability; Nei's genetic distance and identity (Nei, 1978); and Fisher's exact test, applied to the differences in marker frequencies between pairs of populations (the standard error was calculated using 100 batches of 1,000 permutations per batch and 2000 de-memorization steps).

Genotypic diversity between populations was tested by applying the $G$-test to allele frequencies at the loci, using the population genetics package POPGENE 1.31 (Yeh et al., 1997). To get a clear overall picture of the $G$-test results we calculated the 'proportion of significance', defined as the number of RAPD loci with significant $(\mathrm{p}=0.05 \%) G$-test differences between allele frequencies in different populations divided by the total number of polymorphic loci.

Twelve of the 40 primers screened produced clear RAPD patterns consisting of a total of 206 loci, 129 of which were polymorphic ( $95 \%$ criterion). A RAPD electrophoretic profile is shown in Figure 2, for one of the selected primers. The number of bands per primer varied from 11 to 25 . No population-specific band was observed. Very similar proportions of polymorphic loci $(\bar{P})$ were found in the three populations: $57.28 \%(\mathrm{GF}), 58.74 \%(\mathrm{SF})$ and 59.22 (AT), with an overall mean of $58.41 \%$. The estimated of average heterozygosity $(\bar{H} e)$ for bees from the three areas were also very alike: 0.1924 (SF), 0.1959 (GF) and 0.1961 (AT), indicating similar levels of genetic variability.

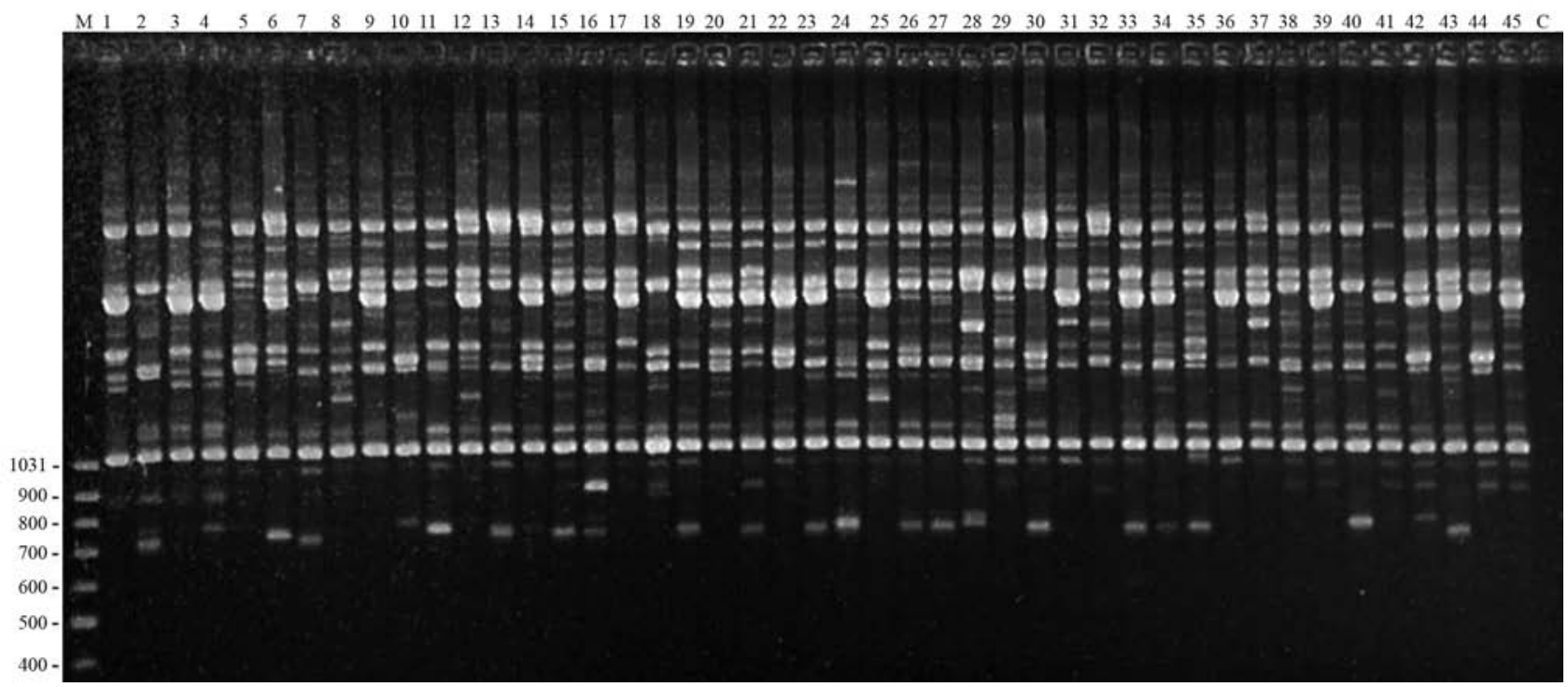

Figure 2 - DNA polymorphism (investigated using primer OPC9) of 45 Eufriesea violacea males from three rainforest fragments. Column M shows the 100 bp molecular weight marker (Biotools); columns 1 to 15 show the results for the São Francisco Park samples (SF); columns 16 to 30 show the results for the Godoy Forest samples (GF); columns 31 to 45 show the results for the Arthur Thomas Park samples $(\mathrm{AT})$, and C = control. 
Research on male euglossines in the Amazon Forest suggests that forest fragments of small sizes $(<100 \mathrm{ha})$ could compromise the survival of some euglossine species, which have declined in numbers of individuals after forest fragmentation (Powell and Powell, 1987). Although the smallest rainforest fragment (AT) studied by us was only about 84 ha $E$. violacea males from this fragment showed a similar proportion of polymorphic loci to the other two rainforest fragments, suggesting that the size of the rainforest fragments did not affect the genetic variability of the E. violacea population living in them. Reinforcing this idea, the estimated average heterozygosity $(\bar{H} e)$ indicated similar levels of genetic variability among the three populations.

Euglossine bees are considered strong fliers, able to fly considerable distances across lakes and forests (Janzen, 1971; Dressler, 1982). A study by Murren (2002) at Panamá has shown that Eulaema cingulata (Fabricius) from a mainland site visited bait traps on an island $500 \mathrm{~m}$ away. Also, a number of euglossine species have been observed moving between Brazilian rainforest remnants (Raw, 1989; Tonhasca et al., 2003), although other studies carried out in Brazil have shown that males from some euglossine bee species do not cross the intervening matrix between forest fragments (Powell and Powell, 1987; Peruquetti et al., 1999).

Our estimates of Nei's (1978) unbiased genetic distances ranged from 0.0171 to 0.0284 and genetic identity from 0.9720 to 0.9831 (Table 1), the highest genetic identity being between bees from the larger SF and GF fragments $60 \mathrm{Km}$ apart. The highest genetic distance (0.284), and therefore the lowest genetic identity (0.9720), occurred between bees from the SF and AT fragments.

In our study, the values of Fisher's exact test between pairs of E. violacea populations from the three rainforest fragments $(\mathrm{SG}-\mathrm{GF}=172.41$; SF-AT $=222.54$; GF-AT $=$ 219.27) indicated the there were no significant differences between pairwise populations $(p>0.05)$ and hence no genetic differentiation among the three populations. Also, the analysis of genotypic diversity by the $G$-test showed little variation between groups of individuals from different fragments, with significance proportion values ranging from $11.38 \%$ (SF-AT) to $15.90 \%$ (GF-AT).

Since $E$. violacea is a very seasonal euglossine species with just one generation per year (Wittmann et al.,

Table 1 - Unbiased Nei's (1978) genetic distances (lower-left) and genetic identity (upper-right) between pairs of three Eufriesea violacea populations from São Francisco State Park (SF), Godoy's Forest State Park (GF) and the Arthur Thomas Municipal Park (AT).

\begin{tabular}{lccc}
\hline Population & SF & GF & AT \\
\hline SF & - & 0.9831 & 0.9720 \\
GF & 0.0171 & - & 0.9761 \\
AT & 0.0284 & 0.0242 & - \\
\hline
\end{tabular}

1989; Peruquetti and Campos, 1997) it is possible that the three populations of $E$. violacea studied have maintained themselves genetically similar to native populations originally present in the tropical rainforest before fragmentation took place, this conjecture being reinforced by the fact that the genetic distance lowest value occurred between bees from the GF and SF fragments (Table 1).

Since male euglossines are not tied to a nest but leave it upon hatching, the occurrence of a single panmitic E. violacea population among the three rainforest fragments studied could also be due to the fact that males are able to move between nearby fragments. Our results appear to support this hypothesis because the AT fragment population was more similar to the GF fragment population than to the SF population (Table 1), indicating that some bees could be migrating between the AT and GF fragments. Tonhasca et al. (2003) observed that male euglossine bees were able to move within and between forest patches and proposed that the long-established fragments surrounding the larger forest remnant of Atlantic

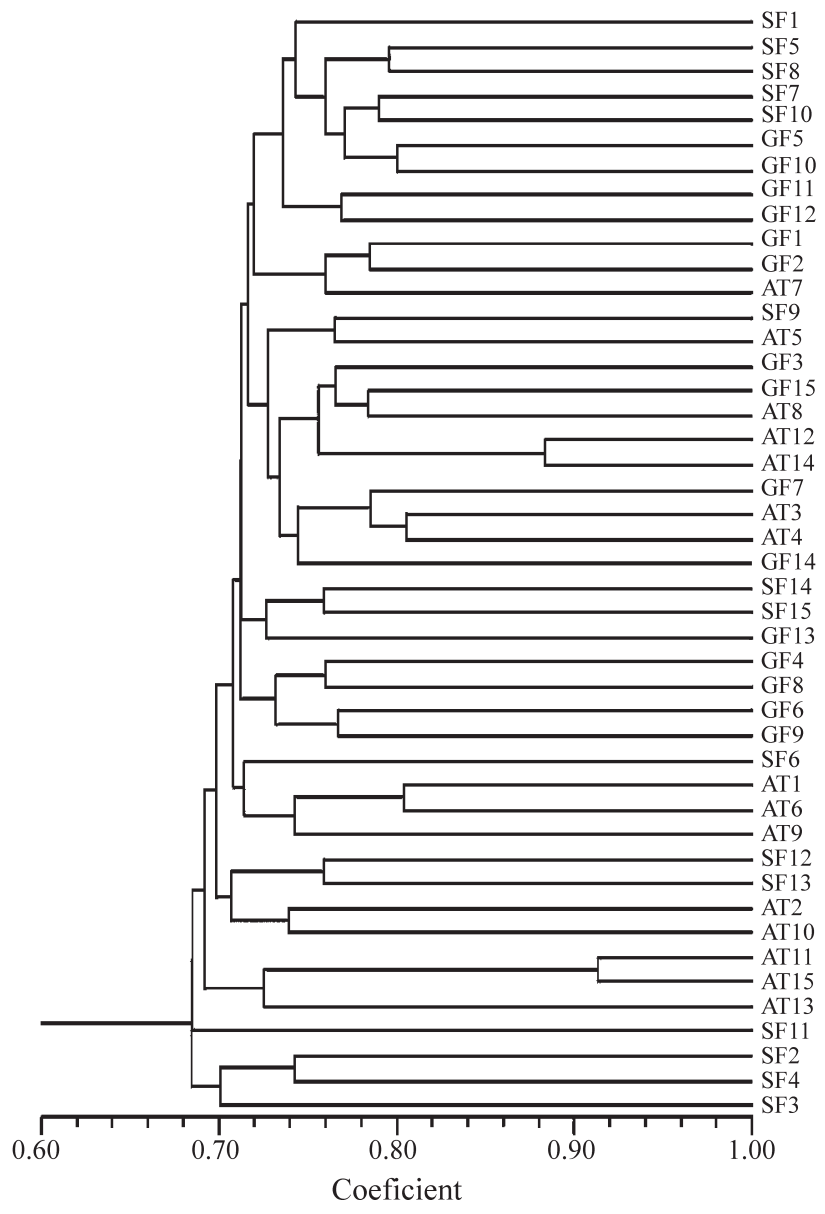

Figure 3 - Dendrogram constructed using the Jaccard coefficient and the unweighted pair group method with averages (UPGMA) method for Eufriesea violacea males from three forest remnants in northern Paraná, Brazil. SF = São Francisco State Park, GF = Godoy Forest, AT = Arthur Thomas Park. 
rainforest were functionally connected with regard to euglossine bee dispersal.

The $E$. violacea males from the three rainforest fragments showed a mean coefficient of similarity (calculated for all pair-wise comparisons) of 0.71 , ranging from 0.91 between bees AT11 and AT15 (Figure 3), which exhibited very similar RAPD banding patterns, to about 0.62 for bees from more distantly-separated forest fragments (AT13 and SF4; GF13 and SF4). These results suggest only a moderate degree of genetic diversity among males of this species in the three forest remnants studied (Figure 3), and $G$-test analysis of the genotypic diversity showing little variation between groups of individuals from different fragments lends support to this idea.

Overall, our results suggest that in spite of habitat fragmentation resulting from intense anthropogenic interference to this Brazilian rainforest $E$. violacea populations are maintaining satisfactory levels of genetic variability. Such findings may influence proposed strategies for conservation of both these Neotropical pollinators and the Atlantic rainforest remnants of southern Brazil.

\section{Acknowledgments}

The authors are grateful to the Secretaria Municipal do Ambiente-Londrina (SEMA), Instituto Ambiental do Paraná (IAP) and the Instituto Brasileiro do Meio Ambiente e dos Recursos Naturais Renováveis (IBAMA) for permission to collect bees and to the anonymous referees who contributed with valuable suggestions. This study was supported by grants from Fundação O Boticário de Proteção à Natureza (FBPN) - project n. 511/20012.

\section{References}

Ackerman JD (1983) Diversity and seasonality of male euglossine bees (Hymenoptera, Apidae) in Central Panama. Ecology 64:274-283.

Allnut TR, Newton AC, Premoli A and Lara A. (2003) Genetic variation in the threatened South American conifer Pilgerodum uviferum (Cupressaceae), detected using RAPD markers. Biol Conserv114:243-253.

Almeida FS, Fungaro MHP and Sodré LMK (2001) RAPD and isoenzyme analysis of genetic variability in three allied species of catfish (Siluriformes, Pimelodidae) from the Tibagi river, Brazil. J Zool 253:113-120.

Becker P, Moure JS and Peralta FJA (1991) More about Euglossine bees in Amazonian forest fragments. Biotropica 23:586-91.

Cameron SA (2004) Phylogeny and biology of Neotropical orchid bees (Euglossini). Ann Rev Entomol 49:377-404.

Dodson CH (1966) Ethology of some bees of the tribe Euglossini (Hymenoptera, Apidae). J Kansas Entomol Soc 39:607-629.

Dressler RL (1982) Biology of orchid bees (Euglossini). Ann Rev Ecol Sys 13:373-394.

Fergunson AJBT, Prodöhl PA, Mcmeel O, Thompson C, Stone C, Mcginnity P and Hynes RA (1995) The application of molecular markers to the study and conservation of fish population, with special reference Salmo. J Fish Biol 47:103-126.
Fernandes A and Bezerra P (1990) Estudo Fitogeográfico do Brasil. Stylus Comunicações, Fortaleza, 205 pp.

Garófalo CA, Camillo E, Augusto SC, Jesus BMV and Serrano JC (1998) Diversidade, abundância sazonal de Euglossini (Hymenoptera, Apidae) na Serra do Japi, Jundiaí, SP. Anais 3:72-79. IV Simpósio de Ecossistemas Brasileiros, Águas de Lindóia, Brazil.

Janzen DH (1971) Euglossine bees as long-distance pollinators of tropical plants. Science 171:203-205.

Jesus BMV and Garófalo CA (2000) Riqueza e abundância sazonal de Euglossini (Hymenoptera, Apidae) na Mata da Virgínia, Matão, São Paulo. Anais 4:239-245. Encontro Sobre Abelhas, Ribeirão Preto, Brazil.

Kimberling DN, Ferreira AR, Shuster SM and Keim P (1996) RAPD marker estimation of genetic structure among isolated northern leopard frog, populations in the south-western USA. Mol Ecol 5:519-529.

Lynch M and Milligan BG (1994) Analysis of population structure with RAPD markers. Mol Ecol 3:91-99.

Maack R (2002) Geografia Física do Estado do Paraná. $3^{\text {a }}$ edição. Imprensa Oficial, Curitiba, $440 \mathrm{pp}$.

Miller MP (1997) Tools for population genetic analyses (TFPGA) 1.3: A Windows program for the analysis of allozyme and molecular population genetic data. Computer software distributed by author.

Murren CJ (2002) Effects of habitat fragmentation on pollination: Pollinators, pollinia viability and reproductive success. J Ecol 90:100-107.

Nei M (1978) Estimation of average heterozygosity and genetic distance from a small number of individuals. Genetics 89:583-590.

Peruquetti RC and Campos LAO (1997) Aspectos da biologia de Euplusia violacea (Blanchard) (Hymenoptera, Apidae, Euglossini). Rev Bras Zool 14:91-97.

Peruquetti RC, Campos LAO, Coelho CDP, Abrantes CVM and Lisboa LCO (1999) Abelhas Euglossini (Apidae) de áreas de Mata Atlântica: Abundância, riqueza e aspectos biológicos. Rev Bras Zool 16 (Supl. 2):101-118.

Powell AH and Powell GNN (1987) Population dynamics of male euglossine bees in Amazonian forest fragments. Biotropica 19:176-179.

Raeder U and Broda P (1985) Rapid preparation of DNA from filamentous fungi. Lett Appl Microbiol 1:17-20.

Raw A (1989) The dispersal of euglossine bees between isolated patches of eastern Brazilian wet forest (Hymenoptera, Apidae). Rev Bras Entomol 33:103-107.

Rebêlo JMM and Garófalo CA (1991) Diversidade e sazonalidade de machos de Euglossini (Hymenoptera, Apidae) e preferências por iscas-odores em um fragmento de floresta no sudeste do Brasil. Rev Bras Biol 51:787-799.

Rohlf FJ (1992) NTSYS-pc Numeral taxonomy and multivariate analysis system. Exeter Software, Applier Biostatistics, NY, $225 \mathrm{pp}$.

Santos AM and Sofia SH (2002) Horário de atividade de machos de Euglossinae (Hymenoptera, Apidae) em um fragmento de floresta semidecídua no norte do estado do Paraná. Acta Scientiarum 24:375-381.

Sneath PHA and Sokal RR (1973) Numerical Taxonomy: The Principles and Practice of Numerical Classification. W.H. Freeman, San Francisco, 573 pp. 
Sofia SH and Suzuki KM (2004) Comunidades de abelhas Euglossina (Hymenoptera, Apidae) em fragmentos florestais no sul do Brasil. Neotrop Entomol 33:693-702.

Tonhasca A, Albuquerque GS and Blackmer JL (2003) Dispersal of euglossine bees between fragments of the Brazilian Atlantic Forest. J Trop Ecol 19:99-102.

Williams JGK, Kubelik AR, Livak KL and Tingey SV (1990) DNA Polymorphism amplified by arbitrary primers are useful as genetic markers. Nucl Acids Res 18:6531-6535.
Wittmann D, Radtke R and Blochtein B (1989) Seasonality and seasonal changes in preferences for scent baits in Euplusia violacea in Rio Grande do Sul/Brazil. Entomol Gen $14: 217-221$

Yeh FC, Yang R-C, Boyle TBJ, Ye Z-H and Mao JX (1997) POPGENE, the user-friendly shareware for population genetic analysis. Molecular Biology and Biotechnology Centre, University of Alberta, Canada. Available at http://www.ualberta.ca/ fyeh/faq.htm

Associate Editor: Louis Bernard Klaczko 